\title{
HUBUNGAN PERSEPSI SISWA TERHADAP SARANA BELAJAR GAMBAR DENGAN HASIL BELAJAR MATA DIKLAT GAMBAR TEKNIK PADAKELAS X TEKNIK PERMESINAN DI SMK NEGERI 1 LINTAU BUO KABUPATEN TANAH DATAR
}

\section{RELATIONSHIP OF STUDENTS PERCEPTION OF MEANS OF LEARNING PICTURES WITH EARLY LEARNING OUTCOMES IN THE PICTURE OF TECHNIQUESCLASS $X$ MACHINERY ENGINEERING INSTATE 1ST VOCATIONAL SCHOOL, LINTAU BUO TANAH DATAR DISTRICT}

\author{
Herki Mahendra $^{(1)}$, Syahrul ${ }^{(1)}$. Budi Syahri ${ }^{(1)}$. \\ Jurusan Teknik Mesin, Fakultas Teknik, Universitas Negeri Padang \\ Kampus Air Tawar, Padang 25131, Indonesia \\ herkimahendra223@gmail.com \\ syah aura@yahoo.co.id \\ budisyahri@ft.unp.ac.id
}

\begin{abstract}
Abstrak
Permasalahan yang berhubungan dengan rendahnya hasil belajar siswa diperkirakan adanya permasalahan yang menyangkut tentang persepsi siswa terhadap sarana belajar Gambar. Tujuan dari penelitian ini adalah untuk mengetahui hubungan persepsi siswa terhadap sarana belajar Gambar Teknik Permesinan tahun ajaran 2018/2019 dengan hasil belajar mata diklat Gambar Teknik pada Kelas X Teknik Permesinan di SMK Negeri 1 Lintau Buo. Jenispenelitian ini bersifat korelasional. Populasi dalam penelitian ini berjumlah 64 siswa di SMK Negeri 1 Lintau Buo. Sampel diambil dari populasi yang ada dari setiap kelas dengan menggunakan rumus Slovin sehingga didapatkan sampel sebanyak 40 siswa. Pengambilan data penelitian dilakukan dengan menyebarkan angket model skala likert yang telah di uji validitas dan realibilitasnya. Data yang dikumpul tersebut dianalisis secara statistik dengan bantuan komputer program SPSS versi 16.00 for windows. Hasil penelitian terdapat hubungan yang signifikan antara persepsi siswa terhadap sarana Gambar dengan hasil belajar mata diklat Gambar siswa kelas X Teknik Permesinan di SMK Negeri 1 Lintau Buo. Adanya hubungan yang berarti tersebut ditunjukkanoleh perolehan nilai $\mathrm{r}$ hitung $=0,454 \geq \mathrm{r}$ tabel 0,312 , maka berdasarkan tabel pedoman interprestasi koefisien korelasi maka tingkat hubungan persepsi siswa terhadap sarana belajar Gambar dengan hasil belajar mata diklat gambar teknik dikategorikan "sedang"
\end{abstract}

Kata Kunci : Persepsi, Siswa, Sarana belajar, Gambar Teknik, Hasil Belajar.

\begin{abstract}
Problems related to the low student learning outcomes are thought to be problems that concern students' perceptions of the learning tools of Pictures. The purpose of this study was to determine the relationship between students' perceptions of the learning facilities of Mechanical Engineering Pictures for the 2018/2019 school year with the results of the Engineering Drawing training eye learning in Class X of Mechanical Engineering at SMK Negeri 1 Lintau Buo. This type of research is correlational. The population in this study amounted to 64 students at SMK Negeri 1 Lintau Buo. Samples were taken from the existing population from each class using the Slovin formula so that a sample of 40 students was obtained. Data retrieval research is done by distributing Likert scale model questionnaires that have been tested for validity and reliability. The data collected was analyzed statistically with the help of a computer program SPSS version 16.00 for Windows. The results of the study there is a significant relationship between students' perceptions of the means of drawing with the learning outcomes of training images in class X students of Mechanical Engineering at SMK Negeri 1 Lintau Buo. The existence of a meaningful relationship is shown by the acquisition of $r$ count $=0.454$ $\geq r$ table 0.312, then based on the guideline table interpretation of correlation coefficients the level of relationship of student perceptions of learning facilities Figure with learning outcomes of technical drawing training courses are categorized as "moderate"

Keywords: Perception, Students, Learning Facilities, Engineering drawings, Learning Outcomes.
\end{abstract}





\section{Pendahuluan}

Pendidikan adalah alat untuk mengembangkan dan meningkatkan kualitas sumber daya manusia. Pendidikan diharapkan bisa menimbulkan perubahan pada diri seseorang seperti aspek kognitif, efektif dan psikomotor (Jasman : 2018). Proses dari pendidikan memberikan pengetahuan, keterampilan dan juga sikap yang dibutuhkan didunia kerja. Pendidikan formal yang bertangung jawab pada sumber daya manusia yang terampil dan siap masuk dunia kerja adalah Sekolah Menengah Kejuruan atau SMK (Waskito : 2016). Sekolah merupakan lembaga pendidikan tempat proses belajar mengajar berlangsung. Dengan proses inilah tujuan pendidikan akan tercapai dalam bentuk perubahan tingkah laku siswa (Ambiyar : 2016).

Salah satu penyebab yang dapat mempengaruhi hasil belajar adalah sarana yang digunakan pada saat berlangsungnya proses belajar mengajar di kelas. Tingkat ketuntasan minimum di SMK Negeri 1 Lintau Buo pada mata diklat gambar teknik adalah 75 sedangkan di sekolah tersebut masih banyak siswa yang mendapatkan hasil belajar yang di bawah KKM khususnya di mata diklat gambar teknik. Dalam proses belajar persepsi siswa terhadap sarana memegang peranan yang penting agar proses belajar berjalan dengan lancar. Sarana memegang peranan yang penting untuk kelancaran proses belajar siswa. Sarana yang diperlukan siswa untuk mata diklat gambar teknik seperti, ruangan belajar gambar, penerangan, ventilasi, kertas gambar, pensil, jangka, sepasang segi tiga, busur drajat.

Persepsi Siswa Terhadap kondisi sarana belajar baik berupa sumber belajar teori maupun media praktek sangat berpengaruh dalam kegiatan belajar dan pencapaian hasil belajar. Sarana belajar siswa di sekolah perlu didukung dengan sarana belajar di rumah, hal ini selain untuk meningkatkan dan menambah keterampilan siswa dalam menggambar serta untuk menutupi keterbatasan belajar di sekolah pada mata diklat gambar teknik. Gambar teknik merupakan mata diklat yang sangat penting untuk diketahui dan dimengerti siswa, karena gambar teknik merupakan salah satu alat komunikasi yang mempunyai peranan yang cukup besar dalam mendukung perkembangan dunia teknologi dan industri, orang menggunakan gambar sebagai alat komunikasi dalam bidang teknik dan industry (Said Sugardi : 1986). Shadily (1982) mengemukakan bahwa "persepsi adalah tanggapan daya memahami atau daya untuk memahami suatu objek. Faktor internal dan eksternal mempengaruhi hasil belajar. Faktor internal dapat mempengaruhi IQ, minat, bakat, persepsi, harapan, ketekunan dan lainlain. Kemudian faktor eksternal mempengaruhi oleh kurikulum, managemen, ekonomi, sosial, dan para guru yang terdiri dari berbagai faktor seperti media, bahan ajar dan waktu belajar Suparno (2017).

Menurut pendapat para ahli di atas dapat disimpulkan bahwa persepsi adalah pendapat, penilaian atau gambaran seseorang mengenai suatu objek melalui sistem konseptual dan panca indranya yang sangat menentukan reaksi terhadap suatu objek. Persepsi dapat juga diartikan bagaimana seseorang mengamati dan memandang situasi atau keadaan tertentu. Wahyuningrum (2004: 5) mengatakan sarana adalah semua fasilitas yang dibutuhkan dalam proses belajar, meliputi fasilitas bergerak maupun fasilitas yang tidak bergerak agar proses belajar berjalan lancar.

Roestiyah (2001) sarana belajar adalah peralatan belajar yang dibutuhkan dalam proses belajar agar pencapaian tujuan belajar dapat berjalan dengan lancar, teratur, efektif dan efisien Sarana belajar adalah seluruh perlengkapan, bahan dan perabotan yang digunakan secara langsung dipergunakan dalam proses pembelajaran. Sarana gambar teknik adalah perlengkapan dan peralatan yang digunakan langsung untuk menunjang kegiatan pembelajaran, khususnya pada pelajaran Gambar Teknik, contohnya kertas gambar, pensil, penghapus, peruncing pensil, serta alat-alat dan media yang menunjang pengajaran gambar teknik lainnya. Slameto (1995) mengatakan Sarana sangat berhubungan dengan proses belajar siswa, karena sarana belajar yang digunakan guru pada jam pelajaran berlangsung juga digunakan siswa untuk mengetahui bahan ajar yang diberikan erat hubungannya dengan cara belajar siswa, karena sarana pelajaran yang dipakai guru pada waktu mengajar di pakai pula oleh 
siswa untuk menerima bahan yang diajarkan, maka apa yang diajarkan guru akan mudah dimengerti siswa. Gambar adalah goresan suatu bentuk yang sangat jelas, ide atau rencana yang dibuat untuk kontruksi suatu benda. Metode untuk membuat suatu gambar yang jelas adalah sebuah bentuk alami dari komunikasi ide-ide umum. Pada dunia teknik, gambar yang berhubungan dengan keteknikan disebut dengan menggambar teknik. Gambar teknik adalah gambar yang berupa simbol, garis serta tulisan yang bisa memberikan komunikasi kepada seorang mekanik sebagai suatu petunjuk untuk pekerjaan. Juana, dan M. Suratman (2000) Gambar teknik adalah suatu komunikasi untuk menyampaikan ide atau gagasan para ahli teknik. Gambar teknik juga sering diartikan sebagai bahasa teknik. Menurut Nana sudjana (2004: 3) "Hasil belajar siswa adalah perubahan prilaku dalam artian yang luas. Hasil belajar ini diperoleh melalui penilaian. Nasution S (1982) mengemukakan bahwa penilaian dilakukan untuk membuat keputusan dengan cara mengukur hasil belajar dari siswa. Slameto (1995) Hasil belajar adalah pengalaman yang dialami individu setelah melakukan interaksi dengan lingkungannya sebagai salah satu proses dalam memperoleh suatu perubahan sikap. Hasil belajar dikategorikan menjadi 3 bagian yaitu: (1) ranah kognitif, (2) sikap yang berkenaan dengan ranah afektif, dan (3) hasil belajar kemampuan dan keterampilan berkenaan dengan ranah Winkel (1996). Maka dari itu dilakukan test untuk mengetahui prestasi siswa, baik itu test lisan, test tertulis maupun tes tingkah laku, nantinya test ini yang akan menentukan dari hasil belajar siswa. Kriteria mutlak adalah membandingkan hasil penilaian dengan kriteria yang sudah pasti, sedangkan membandingkan hasil dari penilaian antar kelompok disebut dengan kriteria relatif.

Hasil belajar pada mata diklat gambar teknik adalah kemampuan yang dimiliki oleh setiap siswa dalam penguasaan materi gambar, serta kemampuan untuk menggambar yang diketahui dari hasil tes psikomotor siswa. Pencapaian hasil belajar siswa tidak akan terjadi apabila siswa tidak secara langsung ikut serta dalam proses belajar secara serius dan tekun. Persepsi siswa terhadap kondisi sarana belajar baik berupa sumber belajar teori maupun media praktek sangat berpengaruh dalam kegiatan belajar dan pencapaian hasil belajar. Sarana belajar siswa disekolah perlu didukung dengan sarana belajar dirumah, hal ini selain untuk meningkatkan dan menambah keterampilan siswa dalam keahlian menggambar serta untuk menutupi keterbatasan belajar di sekolah pada mata diklat gambar teknik. Sarana belajar sebagai salah satu penunjang keberhasilan pendidikan, karena dapat memacu semangat siswa dalam belajar. Halangan yang sering terjadi adalah adanya indikasi sarana belajar siswa yang kurang pada mata diklat gambar teknik. Terdapatnya hubungan antara persepsi siswa terhadap sarana belajar menggambar dengan hasil belajar pada matadiklat gambar teknik. Sarana akan memberikan dampak yang positif terhadap hasil belajar. Siswa yang memanfaatkan sarana belajar dengan baik akan mendapatkan hasil belajar yang tinggi sedangkan siswa yang tidak sama sekali memanfaatkan sarana maka hasil belajarnya akan rendah.

Hasil dari observasi yang dilakukan penulis pada waktu melakukan praktek lapangan kependidikan juli - desember tahun 2017 di SMK Negeri 1 Lintau Buo, penulis mendapatkan data hasil belajar siswa dari guru mata pelajaran gambar teknik. Dari data tersebut terdapat masih banyak siswa yang belum mencapai KKM yaitu masih dibawah nilai 75,00 . Salah satu penyebabnya adalah kurangnya sarana gambar yang dimiliki SMK negeri 1 Lintau buo.

\section{Metode Penelitian}

Jenis penelitian ini tergolong pada penelitian korelasi. Margono (1997) menjelaskan bahwa "penelitian korelasi adalah penelitian yang bermaksud untuk mengetahui hubungan antara dua gejala atau lebih".

\section{A. Populasi}

Menurut Suharsimi Arikunto (2002) populasi adalah keseluruhan subjek penelitian. Populasi pada penelitian ini adalah siswa kelas X TP 1 dan X TP 2 yang terdaftar pada Tahun Ajaran 2018/2019 di SMK Negeri 1 Lintau Buo yang berjumlah 
berjumlah 64 orang siswa dengan rincian seperti pada tabel:

Tabel 1. Jumlah Siswa Kelas X TP di SMK Negeri 1 Lintau Buo Tahun ajaran 2018/2019

\begin{tabular}{cc}
\hline Kelas & Populasi \\
\hline X TP 1 & 32 Orang \\
X TP 2 & 32 Orang \\
Jumlah & 64 Orang
\end{tabular}

Sumber : SMK Negeri 1 Lintau Buo

\section{B. Sampel Penelitian}

Sugiyono (2003) Sampel adalah bagian dari jumlah dan karakteristik yang dimiliki oleh populasi tersebut. Untuk menentukan jumlah sampel maka penulis menggunakan rumus dari Riduwan (2004: 65) sebagai berikut:

$n=\frac{N}{1+N e^{2}}$

Keterangan :

$\mathrm{n}=$ besar sampel.

$\mathrm{N}=$ besar populasi.

$\mathrm{e}=$ persen kelonggaran ketidak telitian karena kesalahan pengambilan sampel yang masih dapat di tolerir atau diijinkan sebesar $10 \%$.

Rumus tersebut dapat diperoleh jumlah sampel untuk siswa sebagai berikut:

$n=\frac{N}{1+N e^{2}}$

$n=\frac{64}{1+64.0,1^{2}}$

= 39,02 dibulatkan menjadi 40 orang sampel.

Jumlah sampel dalam penelitian ini adalah sebanyak 40 orang yang tersebar pada dua kelas, untuk menetapkan anggota sampel per kelas dilakukan perhitungan sebagai berikut:

$\frac{\text { Jumlah siswa per kelas }}{64} \times \quad 100 \% \begin{array}{r}= \\ \text { kelampel per }\end{array}$

Besarnya sampel untuk setiap kelas dapat dilihat dari table 2 berikut.

Tabel 2.Sampel Penelitian

\begin{tabular}{cc}
\hline Kelas & Sampel \\
\hline X TP & 20 Orang \\
X TP & 20 Orang \\
Jumlah & 40 Orang \\
\hline
\end{tabular}

Sampel akan diambil 20 siswa perkelas dan cara pengambilan sampel akan dilakukan dengan Random Sampling.

\section{Uji Coba Instrumen}

Instrumen pengumpulan data ialah alat yang digunakan untuk pengumpulan data agar kegiatan tersebut menjadi mudah Bulkia Rahim (2018). Sebelum dilakukan instrumen penelitian, terlebih dahulu di uji coba, uji coba ini dilakukan untuk memeriksa kesahihan atau validitas, serta realibilitas atau kehandalan, sehingga nantinya angket tersebut memenuhi kriteria untuk digunakan. Pengujian ini dilakukan kepada kelas $\mathrm{X}$ Teknik Permesinan di SMK Negeri 1 Lintau Buo sebanyak 24 orang.

1. Uji Validitas

Suharsimi Arikunto (1996) mengatakan Validitas adalah keadaan yang menggambarkan tingkat instrumen yang bersangkutan mampu mengukur apa yang di ukur. Untuk pengujian validitas instrumen, menggunakan rumus Suharsimi Arikunto (2010) Product Momen yaitu ;

Dasar dalam pengambilan keputusan dinyatakan valid adalah :

1. jika $\mathrm{r}$ hitung $>\mathrm{r}$ tabel maka item tes tersebut dinyatakan valid.

2. jika $r$ hitung $<\mathrm{r}$ tabel maka item tes tersebut dinyatakan tidak valid dan dinyatakan gugur.

Setelah dilakukan analisis validitas angket kreativitas siswa didapat 36 item yang valid dan 4 item yang tidak valid yaitu nomor 32 , 33,34 , dan 38. Untuk selanjutnya item yang tidak valid dibuang dan tidak diikut sertakan sebagai instrumen penelitian.

\section{Uji Reabilitas}

Realibilitas dilakukan untuk mengetahui instrumen yang akan dipergunakan benar-benar reliabel atau handal. Reliabilitas adalah derajat ketetapan, ketelitian atau keakuratan yang ditunjukkan oleh instrumen 
pengukuran. Pada penelitian ini, uji reliabilitas alat ukur yang akan digunakan adalah dengan menggunakan aplikasi SPSS (Special Package for Social Sciences) 16.0 for windows yaitu dengan melihat nilai Cronboach's Alpha dengan ketentuan jika rAlpha negatif dan kecil dari $\mathrm{r}$-tabel berarti tidak reliabel.

Tabel 3. Uji Reabilitas

\section{Reliability Statistics}

\begin{tabular}{|r|l|}
\hline Cronbach's Alpha & N of Items \\
\hline .957 & \\
\hline
\end{tabular}

Dari hasil uji realibilitas maka semua item yang valid dinyatakan reliabel.

\section{Teknik Analisis Data}

\section{Uji Normalitas}

Uji ini dilakukan untuk menguji data yang terkumpul apakah sudah memenuhi syarat untuk dianalisis sesuai dengan tujuan dari penelitian. Tujuan dari Uji Normalitasadalah untuk mengetahui data yang berasal dari populasi berdistribusi normal atau tidak. Prayitno (2008) mengatakan "Uji normalitas dilakukan dengan menggunakan uji one sample Kolmogrov Smirnov dengan menggunakan taraf signifikansi 0,05 atau $5 \%$. Data akan dinyatakan berdistribusi normal jika signifikansi lebih besar dari 5\% atau 0,05". Uji normalitas ini diolah menggunakan program SPSS versi 16.0 for windows.

\section{Uji Linearitas}

Uji ini dilakukan dengan cara mencari persamaan garis variable bebas $(\mathrm{X})$ terhadap variabel terkait(Y). Garis regresi yang telah dibuat, selanjutnya diuji keberartian kofisien garis regresi serta linieritasnya. Uji linieritas dilakukan antara variabel bebas (X) dan variabel terkait (Y) dilakukan dengan menggunakan program SPSS (Special Package Fof Social Sciences) 16.0 For windows.

\section{Uji Hipotesis}

Uji hipotesis ini dilakukan untuk membuktikan apakah hipotesis yang dibuat diterima atau di tolak pada penelitian yang telah dilakukan. Uji hipotesis dilakukan dengan menggunakan analisa korelasi Product Moment.

\section{a. Uji Korelasi Product Moment}

Hipotesis yang diajukan dalam paenelitian ini adalah:

Ha: Terdapat hubungan yang positif dan signifikan antara persepsi siswa tentang sarana belajar gambar dengan hasil belajar pada mata diklat Gambar Tenik kelas X Teknik Permesinan di SMK Negeri 1 Lintau Buo.

Ho: Tidak adanya hubungan yang signifikan dan positif antara persepsi siswa tentang sarana belajar gambar dengan hasil belajar pada mata diklat Gambar Tenik kelas X Teknik Permesinan di SMK Negeri 1 Lintau Buo.

Uji Kolerasi menggunakan rumus korelasi product moment seperti yang dikemukakan Suharsimi Arikunto (2010:213) sebagai berikut:

$$
r_{x y}=\frac{N \sum X Y-\sum X \sum Y}{\sqrt{\left\{N \sum X^{2}-\left(\sum X\right)^{2}\right\}\left\{N \sum Y^{2}-\left(\sum Y\right)^{2}\right\}}}
$$

Dimana :

$$
\begin{array}{ll}
\text { rxy } & =\text { Koefisien korelasi } \\
\mathrm{X} & =\text { Skor setiap item } \\
\mathrm{Y} & =\text { Skor total setiap sampel } \\
\mathrm{N} & =\text { Jumlah responden }
\end{array}
$$

\section{b. Uji Signifikansi}

Uji signifikansi dilakukan dengan menggunakan rumus uji t, dari hasil pengujian di dapat nilai thitung kemudian dibandingkan dengan $t_{\text {tabel. }}$. Penghitungan $t_{\text {tabel }}$ dengan $\alpha=0,05$ dan derajat kebebasannya yaitu: $(\mathrm{dk})=\mathrm{n}-2$. Kriteria dari pengujian ini adalah jika $t_{\text {hitung }}>t_{\text {tabel }}$ pada taraf signifikansi 0,05, maka Ha diterima dan sebaliknya jika $t_{\text {hitung }}<\mathrm{t}_{\text {tabel, }}$ maka Ho diterima.

$t_{\text {hitung }}=\frac{r \sqrt{n-2}}{\sqrt{1-r^{2}}}$

Dimana :

$\mathrm{t}=$ Nilai $\mathrm{t}_{\text {hitung }}$ 


$$
\begin{array}{ll}
\mathrm{r} & =\text { Koefisien korelasi hasil } \\
& \mathrm{r}_{\text {hitung }}\left(\mathrm{r}_{\mathrm{xy}}\right) \\
\mathrm{n} & =\text { Jumlah responden }
\end{array}
$$

Untuk mengetahui kekuatan hubungan variabel, maka dari itu nilai $r$ yang didapatkan diartikan menurut tabel berikut :

Tabel 4. Interpretasi Nilai $r$

\begin{tabular}{ccl}
\hline No & Nilai r & \multicolumn{1}{c}{$\begin{array}{c}\text { Kekuatan } \\
\text { Hubungan }\end{array}$} \\
\hline 1 & $0,8-1$ & Sangat Tinggi \\
2 & $0,6-0,8$ & Tinggi \\
3 & $0,4-0,6$ & Sedang \\
4 & $0,2-0,4$ & Rendah \\
5 & $0,00-0,2$ & Sangat Rendah \\
\hline
\end{tabular}

4. Uji Koefisien Determinan/Kontribusi

Uji ini digunakan untuk menyatakan besar kecilnya sumbangan variabel persepsi siswa tentang sarana belajar gambar (X) terhadap hasil belajar mata pelajaran gambar teknik (Y) dapat diketahui dengan menggunakan rumus kofisien determinasi dengan cara kuadrat dari koefisien kolerasi PPM kemudian dikalikan $100 \%$. Uji ini dilakukan untuk mencari seberapa besar variabel $\mathrm{X}$ (persepsi) mempunyai kontribusi atau ikut menentukan variabel Y (hasil belajar mata pelajaran gambar teknik). Drajat kofisien determinasi dengan menggunakan rumus:

$\mathrm{KD}=\mathrm{r}^{2} \times 100 \%$

Keterangan :

$$
\begin{aligned}
\mathrm{KD} & =\text { Nilai Koefisien Diterminan } \\
\mathrm{r} & =\text { koefisien korelasi }
\end{aligned}
$$

\section{Hasil dan Pembahasan}

\section{A. Deskripsi Data}

Data penelitian ini meliputi variabel bebas yaitu persepsi siswa tentang sarana belajar gambar (X) dan varibel terikat yaitu hasil belajar siswa (Y).Dari penelitian yang telah dilakukan terhadap data, semua data yang diambil telah mencakupi untuk selanjutnya dianalisis. Selanjutnya dapat dinyatakan bahwa deskriptif ini atau informasi mengenai skor total, skor terendah, rata-rata sudah didapatkan. Berikut ini tampilan perhitungan statistik dasar kedua variabel data yang diolah dengan menggunakan program SPSS (Special Package for Social Sciences) 16.0 for windows. Data yang diperoleh dari nilai Ujian Tengah Semester Gambar Teknik siswa kelas $\mathrm{X}$ Teknik Pemesinan di SMK Negeri 1 Lintau Buo Kabupaten Tanah Datar Semester I Tahun Ajaran 2018/2019 dilihat dari tabel 5 sebagai berikut :

Tabel 5. Deskriptif Data

\begin{tabular}{|l|l|l|}
\multicolumn{2}{c|}{ Statistics } \\
\hline & $\begin{array}{l}\text { PERSEPS } \\
\text { I }\end{array}$ & $\begin{array}{l}\text { HASILBELAJ } \\
\text { AR }\end{array}$ \\
\hline N Valid & 40 & 40 \\
Missing & 0 & 0 \\
Mean & 134.68 & 76.80 \\
Std. Error of & 2.624 & 1.108 \\
Mean & 132.50 & 78.00 \\
Median & 116 & 78 \\
Mode & 16.598 & 7.010 \\
Std. Deviation & 275.507 & 49.138 \\
Variance & 67 & 40 \\
Range & 110 & 50 \\
Minimum & 177 & 90 \\
Maximum & 5387 & 3072 \\
Sum &
\end{tabular}

\section{Persepsi Siswa $(\mathrm{X})$}

Data dari Persepsi siswa tentang sarana belajar gambar $(\mathrm{X})$ diambil dengan cara menyebar angket kepada suswa dengan butir item sebanyak 36 pertanyaan yang telah selesai diuji validitas dan realibitasnya. Kemudian angket disebarkan kepada 40 siswa untuk diisi. Dari data tersebut dapat dilihat bahwa distribusi skor jawaban menyebar dari skor terendah 110 sampai tertinggi 177. Distribusi skor tersebut diperoleh rata-rata atau mean 134,68 , skor tengah atau median 132.50 , skor yang sering muncul atau mode 116 dan terakhir standar deviasi sebesar 16,598. Untuk memperoleh gambaran yang jelas mengenai persepsi siswa dapat dilihat dari tabel 6 berikut :

Tabel 6. Distribusi Frekuensi Skor Persepsi Siswa (X) 


\section{PERSEPSI}

\begin{tabular}{|c|c|c|c|c|}
\hline & $\begin{array}{c}\text { Frequenc } \\
\mathrm{y}\end{array}$ & Percent & $\begin{array}{c}\text { Valid } \\
\text { Percent }\end{array}$ & $\begin{array}{l}\text { Cumulativ } \\
\text { e Percent }\end{array}$ \\
\hline Valid 110 & & & & \\
\hline 113 & 2 & 5.0 & 5.0 & 7.5 \\
\hline 114 & 1 & 2.5 & 2.5 & 10.0 \\
\hline 116 & 4 & 10.0 & 10.0 & 20.0 \\
\hline 117 & 2 & 5.0 & 5.0 & 25.0 \\
\hline 120 & 1 & 2.5 & 2.5 & 27.5 \\
\hline 126 & 1 & 2.5 & 2.5 & 30.0 \\
\hline 127 & 1 & 2.5 & 2.5 & 32.5 \\
\hline 129 & 2 & 5.0 & 5.0 & 37.5 \\
\hline 131 & 3 & 7.5 & 7.5 & 45.0 \\
\hline 132 & 2 & 5.0 & 5.0 & 50.0 \\
\hline 133 & 3 & 7.5 & 7.5 & 57.5 \\
\hline 135 & 1 & 2.5 & 2.5 & 60.0 \\
\hline 136 & 1 & 2.5 & 2.5 & 62.5 \\
\hline 140 & 1 & 2.5 & 2.5 & 65.0 \\
\hline 143 & 2 & 5.0 & 5.0 & 70.0 \\
\hline 144 & 1 & 2.5 & 2.5 & 72.5 \\
\hline 145 & 1 & 2.5 & 2.5 & 75.0 \\
\hline 146 & 1 & 2.5 & 2.5 & 77.5 \\
\hline 147 & 1 & 2.5 & 2.5 & 80.0 \\
\hline 150 & 1 & 2.5 & 2.5 & 82.5 \\
\hline 151 & 1 & 2.5 & 2.5 & 85.0 \\
\hline 153 & 2 & 5.0 & 5.0 & 90.0 \\
\hline 155 & 1 & 2.5 & 2.5 & 92.5 \\
\hline 158 & 1 & 2.5 & 2.5 & 95.0 \\
\hline 176 & 1 & 2.5 & 2.5 & 97.5 \\
\hline 177 & 1 & 2.5 & 2.5 & 100.0 \\
\hline $\begin{array}{l}\text { Tot } \\
\text { al }\end{array}$ & 40 & 100.0 & 100.0 & \\
\hline
\end{tabular}

Persepsi siswa dapat dilihat dari tabel 6 bahwa $42,5 \%$ persepsi siswa tentang sarana belajar gambar diatas skor rata-rata. Jadi dapat disimpulkan bahwa persepsi siswa tentang sarana belajar gambar masih perlu ditingkatkan agar hasil belajar siswa lebih baik dari sebelumnya.
Data dari hasil belajar gambar teknik siswa yang digunakan adalah nilai Ujian Tengah Semester I siswa kelas X Teknik Mesin di SMK Negeri 1 Lintau Buo Tahun Ajaran 2018/2019. Berdasarkan distribusi skor tersebut didapat rata-rata (mean) sebesar 76,80 , skor tengah (median) 78.00, skor yang sering muncul (mode) 78 dan standar deviasi (standard deviation) 7.010.

Tabel 7.Distribusi frekuensi hasil belajar (Y)

HASILBELAJAR

\begin{tabular}{|c|c|c|c|c|}
\hline & $\begin{array}{c}\text { Frequ } \\
\text { ency }\end{array}$ & Percent & $\begin{array}{c}\text { Valid } \\
\text { Percent }\end{array}$ & $\begin{array}{l}\text { Cumulative } \\
\text { Percent }\end{array}$ \\
\hline $\begin{array}{l}\text { Va } 50 \\
\text { lid }\end{array}$ & 2 & 5.0 & 5.0 & 5.0 \\
\hline 70 & 1 & 2.5 & 2.5 & 7.5 \\
\hline 75 & 8 & 20.0 & 20.0 & 27.5 \\
\hline 78 & 19 & 47.5 & 47.5 & 75.0 \\
\hline 80 & 7 & 17.5 & 17.5 & 92.5 \\
\hline 85 & 2 & 5.0 & 5.0 & 97.5 \\
\hline 90 & 1 & 2.5 & 2.5 & 100.0 \\
\hline Total & 40 & 100.0 & 100.0 & \\
\hline
\end{tabular}

Hasil belajar dapat dilihat dari tabel 7bahwa $72,5 \%$ hasil belajar siswa diatas KKM. Jadi dapat disimpulkan bahwa hasil belajar siswa masih perlu ditingkatkan. Selanjutnya untuk histogram distribusi frekuensi skor hasil belajar (Y).

Sesuai dengan tabel 4 nilai pencapaian untuk persepsi siswa adalah sebesar $74.82 \%$ dapat dikategorikan cukup dalam interval 65 $79 \%$. Sedangkan hasil belajar siswa adalah sebesar 76,8 \% dapat dikategorikan cukup dalam interval $65-79 \%$.

\section{B. Teknik Analisis Data}

Teknik analisis yang digunakan adalah teknik korelasi. Berikut syarat yang harus dipenuhi

\section{Hasil Belajar Gambar (Y)}


jika melakukan analisis tersebut. (1) uji normalitas, (2) uji libearitas, (3) uji hipotesis.

\section{Uji Normalitas}

Uji ini dilakukan untuk menguji anggapan bahwa rata-rata sampel mendekati kenormalan populasi. Uji normalitas data ini dibantu dengan program SPSS 16.00 for windows dengan melakukan uji Kolmogorov smirnov (Uji K-S). Signifikansi yang digunakan untuk menolak atau menerima keputusan normal atau tidak suatu distribusi data adalah sebesar 0,05 . Kemudian normal jika skor signifikansi $>\alpha 0,05$. Berikut tabel uju normalitas.

Tabel 8. Uji Normalitas

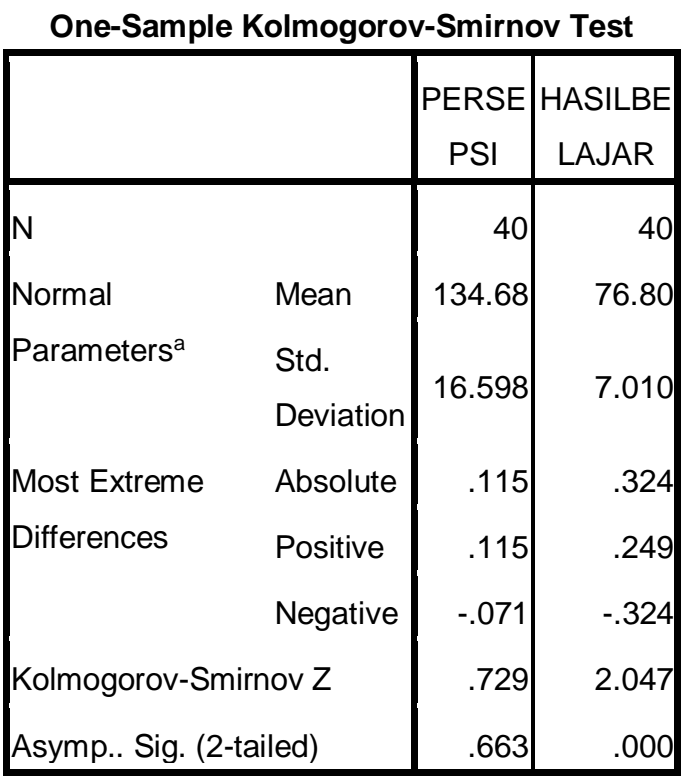

a. Test distribusi is Normal.

\section{Uji Linearitas}

Uji ini dilakukan untuk melihat diantara dua variabel tersebut apakah ada ikatan yang linear atau tidak secara signifikansi. Uji linear ini dilakukan untuk menjadi prasyarat untuk analisis korelasi. Uji linear dilakukan dengan bantuan program SPSS Anova - Test for Linearity dengan pasa taraf signifikansi <alpha (0.05). Hasil uji linearitas data menggunakan program SPSS 16.0 for windows dapat dilihat pada tabel 9 berikut :

Tabel 9. Uji Linearitas

ANOVA $^{\text {b }}$

\begin{tabular}{|c|c|c|c|c|c|}
\hline & Sum of & & Mean & & \\
Model & Squares & Df & Square & F & S3g. \\
\hline
\end{tabular}

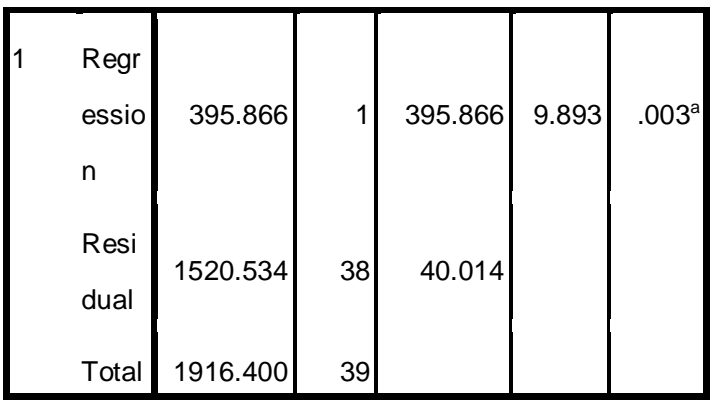

Skor masing-masing variabel mempunyai nilai signifikansi X terhadap Y sebesar 0.003. Karena signifikansi alpha kurang dari 0.05 maka dapat disimpulkan bahwa antara variabel-variabel terdapat hubungan yang linear.

\section{Uji Hipotesis}

Uji hipotesis bertujuan untuk menguji apakah hipotesis yang diajukan diterima atau ditolak. Analisis yang digunakan adalah analisis korelasi. Pengujian hipotesis pada penelitian ini adalah "persepsi siswa tentang sarana belajar gambar $(\mathrm{X})$ dengan hasil belajar siswa dalam mata pelajaran gambar teknik (Y)”. Hasil analisis hipotesis dapat dilihat pada tabel 10 berikut:

Tabel 10. Uji Hipotesis

Correlations

\begin{tabular}{|c|c|c|c|}
\hline & & PERSEPSI & $\begin{array}{c}\text { HASILBELA } \\
\text { JAR }\end{array}$ \\
\hline \multirow[t]{3}{*}{ PERSEPSI } & $\begin{array}{l}\text { Pearson } \\
\text { Correlation }\end{array}$ & 1 & $.454^{* *}$ \\
\hline & Sig. (2-tailed) & & .003 \\
\hline & $\mathrm{N}$ & 40 & 40 \\
\hline \multirow{4}{*}{$\begin{array}{l}\text { HASILBELAJ } \\
\text { AR }\end{array}$} & Pearson & $-151^{* *}$ & 1 \\
\hline & Correlation & & \\
\hline & Sig. (2-tailed) & .003 & \\
\hline & $\mathrm{N}$ & 40 & 40 \\
\hline
\end{tabular}

**. Correlation is significant at the 0.01 level (2-tailed).

Hasil uji hipotesis diatas diperoleh harga koefisisen korelasi antara persepsi siswa tentang sarana belajar gambar (X)hasil belajar gambar teknik (Y) siswa kelas $\mathrm{X}$ Teknik Permesinan di SMK Negeri 1 Lintau Buo di peroleh nilai $\mathrm{R}$ hitung sebesar 0,454 
sementara nilai $\mathrm{R}$ tabel sebesar 0,312 maka $\mathrm{R}$ hitung > $\mathrm{R}$ tabel. Hal ini berarti terdapat hubungan positif antara persepsi siswa tentang sarana belajar gambar dengan hasil belajar gambar teknik. Dengan demikian, $\mathrm{H}_{\mathrm{a}}$ yang menyatakan terdapat hubungan yang signifikan antara persepsi siswa terhadap sarana belajar gambar dengan hasil belajar gambar teknik siswa kelas X Teknik Mesin SMK Negeri 1 Lintau Buo dapat diterima pada taraf kepercayaan 95\%.Uji signifikan dilakukan dengan rumus uji $\mathrm{t}$ sebagai berikut:

$$
\begin{aligned}
t_{\text {hitung }}= & \frac{r \sqrt{n-2}}{\sqrt{1-r^{2}}} \\
& =\frac{0,454 \sqrt{40-2}}{\sqrt{1}-(0,454)^{2}} \\
& =\frac{0,454(6,164)}{\sqrt{0,80}} \\
& =\frac{2,80}{0,90} \\
& =3,111
\end{aligned}
$$

Nilai $\mathrm{t}$ hitung $>\mathrm{t}$ tabel $(3.111>1.684)$ dimana $\mathrm{t}$ tabel diperoleh pada $\alpha=5 \%$ dengan $(\mathrm{df})=$ $\mathrm{n}-2=38$ diperoleh untuk $\mathrm{t}$ tabel sebesar 1,684. Dilihat dari perhitungan diatas maka $\mathrm{H}_{\mathrm{o}}$ ditolak dan $\mathrm{H}_{\mathrm{a}}$ dapat diterima. Selanjutnya bisa dilihat terdapat hubungan yang positif dan berarti antara persepsi siswa tentang sarana belajar gambar dengan hasil belajar Kelas X Teknik Permesinan di SMK Negeri 1 Lintau Buo.

\section{Analisis Determinan Koefisien}

Analisis yang dimaksudkan untuk mencari besarnya sumbangan persepsi siswa tentang sarana belajar gambar kelas X pada Teknik Permesinan dengan hasil belajar gambar teknik di SMK Negeri 1 Lintau Buo. Maka menghitung koefisisen determinan dengan cara mengkuadratkan hasil koefisien korelasi dengan rumus sebagai berikut:

$$
\begin{aligned}
\mathrm{KD}=\mathrm{r}^{2} \times 100 \% & =(0,454)^{2} \times 100 \% \\
& =20,61 \%
\end{aligned}
$$

Hasil analisis diatas maka dapat disimpulkan bahwa besarnya sumbangan persepsi siswa terhadap sarana belajar gambar dengan hasil belajar gambar teknik siswa kelas X Teknik Permesinan di SMK Negeri 1 Lintau Buo Kabupaten Tanah Datar tahun ajaran 2018/2019 adalah sebesar 20,61\%. Hal ini menunjukkan bahwa $20,61 \%$ hasil belajar siswa pada pelajaran gambar teknik ditentukan oleh persepsi siswa terhadap sarana gambar sedangkan 79,39 \% ditentukan oleh faktor lain.

\section{Pembahasan}

Berdasarkan hasil analisis data penelitian dapat ditemukan bahwa terdapat hubungan yang positif dan signifikan antara persepsi siswa tentang sarana belajar gambar dengan hasil belajar pada mata pelajaran gambar teknik, dimana koefisien korelasinya sebesar $\mathrm{r}=0,454$ dan hasil uji nilai t hitung: 3,111 lebih besar dari t tabel: 1,684 disamping itu diperoleh koefisien determinasinya sebesar $20,61 \%$. Hal ini berarti persepsi siswa terhadap sarana gambar memberikan sumbangan sebesar $20,61 \%$ terhadap hasil belajar.

Dari hasil analisis data di atas didapat nilai $r$ sebesar 0,454. Berdasarkan tabel 8 pedoman interprestasi koefesien korelasi maka tingkat persepsi siswa terhadap sarana gambar dikategorikan "sedang".

Hasil penelitian di atas mengemukakan bahwa semakin lengkap sarana belajar siswa semakin baik pula hasil belajar yang dicapainya, karena persepsi siswa terhadap sarana belajar gambar memberikan sumbangan yang positif terhadap hasil belajar siswa, maka perlu dilengkapi sarana belajar siswa tersebut, khususnya pada mata pelajaran gambar teknik.

Hasil analisis data yang dilakukan terdapat hubungan persepsi siswa tentang sarana belajar gambar $(\mathrm{X})$, diperoleh koefisien korelasinya $\mathrm{r}=0,454$ dan koefisien determinasinya 20,61\%. Berarti persepsi siswa tentang sarana belajar gambar memberikan sumbangan sebesar 20,61\% terhadap hasil belajar. Hal ini berarti persepsi siswa tentang sarana belajar gambar memiliki hubungan dengan hasil belajar siswa dalam mata pelajaran gambar teknik.

Jelas bahwa terdapat hubungan yang positif dari persepsi siswa terhadap sarana belajar gambar dengan hasil belajar, atau dengan kata lain dapat dikatakan bahwa seorang 
siswa dapat nilai baik dalam mata pelajaran gambar teknik cenderung memiliki persepsi yang tinggi dan begitu juga sebaliknya. Bagi siswa yang mendapat nilai rendah, perlu meningkatkan persepsi dan lebih giat belajar.

\section{Kesimpulan}

Hasil penelitian dan pembahasan maka dapat diambil beberapa kesimpulan sebagai berikut: adanya hubungan yang positif dan signifikan terhadap persepsi siswa tentang sarana belajar gambar dengan hasil belajar gambar teknik kelas $\mathrm{X}$ jurusan Teknik Pemesinan di SMK Negeri 1 Lintau Buo. Adanya hubungan yang berarti tersebut ditunjukkan oleh $r$ hitung $=0,454 \geq \mathrm{r}$ tabel $=$ 0,312 . Besarnya sumbangan persepsi siswa tentang sarana belajar gambar dengan hasil belajar pada mata pelajaran gambar teknik kelas X SMK Negeri 1 Lintau Buo Tahun Ajaran 2018/2019 adalah sebesar 20,61\% sedangkan 79,39\% ditentukan oleh faktor lain.

\section{Referensi}

Ambiyar dkk. (2016). Penerapan Model Pembelajaran Praktek Terbimbing Mata Diklat Las Busur Manual Untuk Meningkatkan Aktivitas dan Hasil Belajar Praktek Siswa Kelas XI Jurusan Teknik Mesin SMK Muhammadiyah 1 Padang.

Bulkia Rahim dkk. (2018). Validitas Modul Pembelajaran Model Kooperatif Tipe Jigsaw Pada Mata Kuliah Teori Teknik Fabrikasi Vol 1, No. 2.

Husein Umar. (2005) Riset Pemasaran dan Perilaku Konsumen. Jakarta: Gramedia Pustaka Utama

Jasman dkk .(2018). Persepsi Siswa Terhadap Keterampilan Dasar Mengajar Mahasiswa Program Pengalaman Lapangan Kependidikan (PPLK) pada Mata Diklat Gambar Teknik di Smk Negeri 5 Padang

Juana, dan M. Suratman. (2000). Menggambar teknik mesin. Bandung: pustaka Grafika.
Margono. 1997. Metode Penelitian Pendidikan. Semarang: PT Rineka Ciptra.

Nana Sudjana. (1998). Penelitian Hasil Proses Belajar Mengajar, Bandung: PT Remaja Rosdakarya

Nasution. S. 1982. Berbagai Proses dalam Belajar Mengajar. Bandung: Bima Aksara.

Prayitno. (2008). Uji Asumsi Normalitsas dalam SPSS

Roestiyah NK. 2001. Strategi Belajar Mengajar. Jakarta: Rineka Cipta.

Riduwan. (2004). Belajar Mudah Penelitian

Untuk Guru-Karyawan dan Pemula.

Bandung: Albafeta

Said Sugardi. 1986. Dasar-dasar Menggambar Teknik Mesin I. FPTK Ikip Padang.

Shadily.1982. Kamus Bahasa Inggris Indonesia. Gramedia: Jakarta.

Suparno.(2017). Respon Mahasiswa Pembelajaran Kooperatif Jigsaw dan Modul Pembelajaran pada Mata Kuliah Media Pendidikan.

Slameto. 1995. Belajar dan faktor - Faktor yang mempengaruhinya. Jakarta. Rineka Cipta.

Sugiyono. 2003. Metode Penelitian Administarsi. Bandung: Alfabet

Suharsimi Arikunto. 1996. Metode Statistik. Bandung.

. (2002). Prosedur Penelitian. Jakarta: Rineka Cipta

.(2010). Metodologi penelitian. Jakarta: bumi aksara

Wahyuningrum. 2004. Buku ajar Manajemen Fasilitas Pendidikan. Yogyakarta: FIP UN.

Waskito dkk. (2016). Kontribusi Minat Kerja dan Penguasaan Mata Pelajaran Produktif Terhadap Keberhasilan Praktek Kerja Industri Siswa Kelas XII Program Teknik Pemesinan di SMK Negeri 2 Solok. 
Winkel. 1996. Psikologi Pengajaran. Jakarta.

PT. Gramedia Widia darana

Indonesia. 